\title{
Daha İyi Bireysel İş Performansı Arayışında Duygusal Zekanın Etkisinin Test Edilmesi
}

\author{
Ahmet MUMCU ${ }^{1}$ ve Sema YİĞİT²
}

\section{$\ddot{\mathrm{O} z}$}

$\mathrm{Bu}$ araştırmanın amacı duygusal zekanın çalışanların bireysel iş performansları üzerindeki etkisini test etmektir. Araştırmada duygusal zekanın ölçümünde başkalarının duygularını değerlendirme (BDD), kendi duygularını değerlendirme (KDD), duyguların kullanımı (DK) ve duyguların düzenlenmesi (DD) olmak üzere dört boyuttan oluşan Wong ve Law Duygusal Zekâ Ölçeği (WLEIS) kullanılmıştır. Çalışanların iş performansları ölçümünde ise araştırmanın yapıldığı işletmenin oluşturduğu performans kriterleri doğrultusunda belirlenmiş performans puanları kullanılmıştır. Çalışmanın amacı doğrultusunda araştırma verileri 219 çağrı merkezi çalışanından online anket formu ile elde edilmiştir. Araştırma verilerinin test edilmesinde yapısal eşitlik modeli kullanılmıştır. Yapılan analizler neticesinde başkalarının duygularını değerlendirme, kendi duygularını değerlendirme ve duyguların düzenlenmesi boyutlarının çalışanların bireysel iş performansı üzerinde anlamlı bir etkisi olmadığı belirlenmiştir. Duygusal zekanın alt boyutlarından duyguların kullanımının ise iş performansı üzerinde pozitif yönlü anlamlı bir etkiye ( $\beta$ : 0,212; $\mathrm{p}<0.005)$ sahip olduğu tespit edilmiştir.

\section{Anabtar Kelimeler: Duygusal Zekâ, İş Performansı, Çağrı Merkezi Çalışanları}

\section{In The Pursuit of Better Individual Job Performance Testing the Impact of Emotional Intelligence}

\section{Abstract}

The aim of this study is to test the effect of emotional intelligence on employees' individual job performance. The Wong and Law Emotional Intelligence Scale (WLEIS) were adopted to measure the emotional intelligence of employees which is consisted of four dimensions: (1) self-emotional appraisal (SEA), (2) others' emotional appraisal (OEA), (3) use of emotion (UOE), and (4) regulation of emotion (ROE). Performance scores determined in line with the performance criteria established by the company where the research was conducted were used in measuring the job performance of the employees. In the context of the study, research data were obtained from 219 call center employees using an online questionnaire. The structural equation model was used to test the research data. As a result of the analysis, it was determined that the dimensions of self-emotional appraisal, others' emotional appraisal, and regulation of emotion did not have a significant effect on the individual job performance of the employees. However, it was found that the use of emotions dimension had a positive and significant effect $(\beta: 0,212 ; \mathrm{p}<0.005)$ on job performance.

Key Words: Emotional Intelligence, Job Performance, Call Center Employees

\section{Atıf İçin / Please Cite As:}

Mumcu, A. ve Yiğit, S. (2022). Daha iyi bireysel iş performansı arayışında duygusal zekanın etkisinin test edilmesi. Manas Sosyal Araştırmalar Dergisi, 11(1), 230-245.

Geliş Tarihi / Received Date: 24.04.2021

Kabul Tarihi / Accepted Date: 8.07.2021

\footnotetext{
${ }^{1}$ Dr. Öğr. Üyesi. - Tokat Gaziosmanpaşa Üniversitesi Sağlık Bilimleri Fakültesi, ahmet.mumcu@gop.edu.tr ORCID: 0000-0001-6610-5073

2 Prof. Dr. - Ordu Üniversitesi Ünye İ.I.B.F, semayigit@odu.edu.tr

iD ORCID: 0000-0003-4497-7529
} 


\section{Giriş}

Örgütlerin en değerli kaynaklarından biri şüphesiz insan kaynaklarıdır. İnsan kaynağının işinde göstereceği performans örgüt performansına etki etmekte dolayısıyla örgütlerin etkinliği ve devamlılı̆ı konusunda kilit rol oynamaktadır. Çalışanların iş performansına etki eden birçok bireysel ve örgütsel faktör bulunmaktadır. İş performansını etkileyen bireysel faktörlerin neler olduğu konusunda ilk akla gelen bilişsel zekâ, başarı ihtiyacı, azim gibi özellikler olmaktadır. Duyguların çalışma hayatındaki yeri konusunda ise geçmişten günümüze birbiriyle çelişen görüşler sunulmuştur. Önceleri çalışanın işini yaparken duygularını işine karıştırmaması gerektiği düşünülürken, sonraları insan doğası gereği bunun mümkün olamayacağı hatta duyguların çalışanların işlerini daha iyi yapmalarına imkân verebileceği görüşü ortaya çıkmıştır. Özellikle Goleman'ın 1995'te yayınladığı "Duygusal Zekâ Neden IQ'dan Daha Önemlidir?" kitabının bu görüşün kabulünde önemli etkisi olduğu söylenebilir.

Çok sayıda araştırma, üstün performansla bağlantılı yetkinliklerin yaklaşık üçte ikisinin duygusal veya sosyal nitelikler olduğunu göstermektedir (Cherniss, 2000, s. 433-434). Duygusal zekâ hemen hemen her sektörde çalışanın iş performansını etkiliyor olsa da özellikle hizmet sektöründe yer alan ve çalışanların müşterilerle doğrudan etkileşimde bulunduğu işlerdeki etkisi daha fazladır (O'Boyle, Humphrey, Pollack, Hawver ve Story, 2011, s. 793). Çünkü bu işlerde müşterinin istek ve ihtiyaçlarını anlamak, empati yapabilmek veya kendi duygularını yönetmek gibi duygusal yetenekler çalışanın iş performansının önemli parçalarıdır. Ayrıca müșteri ile birebir ilişki içinde olunan ve çok fazla duygusal emek sarf edilen sektörlerde çalışanlar yoğun stresle başa çıkmaya çalışırlar. Duygusal zekâ, çalışanların stresin duygusal etkilerini ve duygusal stresin işyeri performanslanna etkisini hafifletme yeteneklerinde de kritik bir rol oynar (Ashkanasy, Ashton-James ve Jordan, 2003, s. 16).

Hizmet sektörü içerisinde yer alan ve araştırmanın örneklemini oluşturan çağrı merkezlerinde çalışanlar, duyguların kullanılması, düzenlenmesi ve değerlendirilmesi faaliyetlerini yoğun bir şekilde kullanmak zorunda kalabilmektedir ki bu faaliyetler duygusal zekalarının bir yansıması olmaktadır. $\mathrm{Bu}$ bağlamda araştırmanın amacı bu yansımanın çalş̧anların iş performansına etki edip etmediğini belirlemektir.

Bu amaçla önce duygusal zekâ ve iş performansı kavramlarına sonra da bu ikisi arasındaki ilişkilere değinilerek araştırma hipotezi için kavramsal temel oluşturulması sağlanmıştır. Sonrasında kavramsal temeli oluşturulan hipotezlerin test edilmesi için yapılmış olan araştırma hakkında bilgi verilmiş ve analiz sonuçları açıklanmışır.

\section{Duygusal Zekâ}

Thorndike (1920), Guilford (1956) ve daha sonra Gardner'ın (1983) sosyal zekâ üzerine araştırmas1, duyguların entelektüel işleyiş için önemine işaret etse de duygusal zekâ kavramına bir terim olarak ilk defa Mayer, DiPaolo ve Salovey (1990) ile Salovey ve Mayer (1990) çalısmalarında rastlanmaktadır.

Salovey ve Mayer (1990) duygusal zekâ kavramını, bireyin kendisinin ve başkalarının duygularını takip edebilmesi, aralarında ayrım yapması ve elde ettiği bu bilgi ile bireyin düşüncelerine ve eylemlerine rehberlik etmek için kullanılan bir beceri olarak tanımlamışıı. Ayrıca duygusal zekayı, sosyal zekanın bir parçası olarak tanımlamışlardır (Salovey ve Mayer, 1990, s. 189).

Salovey ve Mayer'ın (1990) duygusal zeka kavramını geliştirmelerinde etkisi olan Gardner (1983), çoklu zekâ kuramının ana hatlarını çizerken, kişisel zekanın kişinin kendi duygu hayatına erişebilme yeteneği olan içsel zekâ ve başkalarının ruh hallerini, niyetleri ve arzuları okuma yeteneği olan kişilerarası zekâ olmak üzere iki biçimini tanımlamıştır. Gardner (1983), kişisel zekâları biyolojik temelli biri içe, diğeri dışa doğru ama iç içe geçmiş bilgi işleme kapasiteleri olarak kabul etmiştir. Psikanalizde bu yeteneklere genellikle duygusal öz farkındalık ve empati denmektedir. Kişisel zekanın bu temel yetenekleri, Salovey ve Mayer'in (1990) başlangıçta tanımladığı duygusal zekâ yapısının merkezinde yer almaktadır (Taylor, Parker ve Bagby, 1999, s. 340). 1920'lerde başlayan sosyal zekâ ile ilgili bu gibi çalışmaların kavramın gelişiminde önemli etkileri olmuştur. Bununla beraber Mayer (2001) batı kültüründe düşünce ve duygu arasındaki ilişkilerin felsefi mülahazaları 2000 yıldan daha eskiye dayandığını ifade etmiş ve duygusal zekâ kavramının gelişimini 2001 yllina kadar:

i. 1900-1969 zekâ ve duyguların psikolojik incelemesinin nispeten ayrı olduğu dönem,

ii. 1970-1989 duyguların ve düşüncenin birbirini nasıl etkilediğine odaklanıldığı dönem, 
iii. 1990-1993 duygusal zekanın bir çalışma konusu olarak ortaya çıktı̆̆ dönem,

iv. 1994-1997 kavramın popüler hale geldiği dönem,

v. 1998-2001 duygusal zekâ ile ilgili çalışmaların kavramı netleştirme çabalarının olduğu dönem olmak üzere 5 dönemde ele almıştır (Mayer, 2001, s. 4).

2001 yllından günümüze kadar da duygusal zekâ kavramı üzerinde çokça çalışılmakta ve farklı değişkenlerle ilişkilendirilerek kavrama netlik kazandırma çabaları halen devam etmektedir. Bu çalışmalarda duygusal zekâ kavramı farklı açlardan ele alınmakta ve farklı anlamlarda kullanılmaktadır. Mayer, Salovey ve Caruso (2000b) duygusal zekâ üzerindeki çalışmaların artmasıyla birlikte kavramın üç farklı anlamda kullanıldığını ifade etmişlerdir. İlk ve en kapsamlı anlamında duygusal zekâ, çağa özgü düşünce ve duygu biçimi veya kültürel eğilim gibi bir anlamda kullanılmaktadır. Terimin ikinci ve genel olarak popüler kullanımı, azim, başarı dürtüsü ve sosyal beceriler gibi hayatta başarı için önemli olduğuna inanılan bir grup kişilik özelliğini şeklindedir. Duygusal zekanın üçüncü ve son anlamı ise duygusal bilgiyi işlemeyle ilgili bir dizi yetenek olarak ele alındığı anlamıdır ki (Mayer, vd, s. 92-93) geliştirdikleri model de bu bakış açısını temel almaktadir.

Duygusal zekâ çalışmalarında Reuven Bar-On'un (1988) çalışmaları da önemli rol oynamaktadır. Kendisi duygusal zekayı iyi olma hali ölçüsü açısından değerlendirmeye belki de ilk teşebbüs eden kişi olmuştur. Duygusal zekâ olarak isimlendirilip popülerlik kazanmadan ve Salovey ve Mayer'ın (1990) ilk duygusal zekâ modelini yayınlamalarından daha önce doktora tezinde duygusal katsayı kavramını kullanmıştır (Goleman, 2001, s. 17). Ona göre duygusal ve sosyal zekâ yapısı karmaşık olup kişinin günlük talepler ve baskılarla etkili bir şekilde başa çıkma becerisine etki eden ve birbirleriyle etkileşime giren duygusal, kişisel ve kişilerarası yetenekleri içermektedir (Bar-On, 2000, s. 373). Ayrıca duygusal zekanın insan hayatının performans, mutluluk, refah ve daha anlamlı bir yaşam arayışı gibi pek çok kilit alan üzerinde önemli etkisi olduğunu ifade etmiştir (Bar-On, 2010, s. 59).

1990'da Salovey ve Mayer tarafindan geliştirilen ve daha sonra güncellenen hiyerarşik duygusal zekâ modeli, duygusal zekânın kişinin kendileri ve başklarının duyguların değerlendirilmesi ve bunu ifade etmesi, duygularını kontrol edebilmesi ve sahip olduğu duygusal bilginin sosyal iş ve toplum hayatında fikir ve eylem olarak kullanması olmak üzere üç farklı bileşenden oluşan bir şemsiye kavram olduğunu varsayımına dayanmaktadır (Petrides ve Furnham, 2000, s. 313). Benzer şekilde Goleman (1995) Salovey ve Mayer'ın tanımının duygusal zekayı beş ana alanda ele aldığını ifade etmiştir (Goleman, 1995, s. 43):

- Duygularını Bilmek: Öz farkındalık-bir duyguyu olduğu gibi tanımak-duygusal zekanın temelidir.

- Duyguları Yönetmek: Duyguları uygun olacak şekilde ele almak, öz farkındalı̆̆a dayanan bir yetenektir.

- Kendini Motive Etmek: Bir amaca yönelik duyguları düzenlemek, dikkat göstermek, öz motivasyon ve ustalık için ayrıca yaratıcllık için çok önemlidir.

- Başkalarındaki Duyguları Tanımak: Duygusal öz farkındalığa dayanan başka bir yetenek olan empati, temel insan becerisidir.

- İlişkilerle Başa Çıkmak: İlişki sanatı büyük ölçüde başkalarının duygularını yönetme becerisidir.

Duygusal zekayı ölçmek için Salovey ve Mayer'in yetenek/beceri tabanlı modelinden kısa bir süre sonra başka modeller de geliştirilmiştir. Karma modeller olarak ifade edilen modeller ağırlıklı olarak diğer kişilik ölçütleriyle örtüşen özelliklerin, sosyal becerilerin ve yetkinliklerin bir kombinasyonunu ölçmek için kullanılır. Genel olarak, bu ölçütler kendi kendine raporlama yoluyla veri toplamakla beraber, birkaçı 360 derece değerlendirme biçimlerini de kullanmaktadır (O'Connor, Hill, Kaya ve Martin, 2018, s. 3). Karma duygusal zekâ modelleri, zihinsel yetenek modellerinden önemli ölçüde farkllılk göstermektedir. $\mathrm{Bu}$ modeller yine duygusal zekayı zihinsel yetenek kavramı olarak ele alsalar da bu tür bir zekaya eşlik edebilecek kişilik özelliklerini tanımlamaktadırlar (Mayer, Salovey ve Caruso, 2000a, s. 401).

Düzeyi bireyden bireye farklllık gösteren (Ashkanasy ve Daus, 2002, s. 81) duygusal zekâ kişilerin genel yaşamlarında çeşitli etkilere sahiptir. Salovey ve Mayer (1990)'a göre duygusal zekaya sahip kişiler (Salovey ve Mayer, 1990, s. 201):

- Kendi duygularının ve başkalarının duygularının farkındadır.

- İçsel deneyimin olumlu ve olumsuz yönlerine açıktırlar, onları adlandırabilirler.

- Bu tür bir farkındalık, çoğu kez kendi içinde ve başkalanında duygulanımın etkili bir şekilde düzenlenmesine yol açacak ve böylece iyi olma haline katkıda bulunacaktır. 
- Bu nedenle, duygusal olarak zeki kişi genellikle etrafta olmaktan zevk alır ve başkalarını daha iyi hissettirir.

Böylelikle duygusal zekâ bireyin kendisinin ve diğerlerinin duygularını doğru anlama ve ifade edebilmesini sağlarken duygularını yaşamını iyileştirmek üzere düzenlemeye imkân tanır (Mayer vd., 1990, s. 772).

Duygusal zekanın kişinin genel yaşamında böyle etkileri olduğu ifade edilmekle beraber aslında bu genel yaşamın bir alt kümesi olarak düşünülebilecek kişinin iş yaşamı özelinde de duygusal zekanın etkisi olmasını beklemek doğaldır. Dolayısıyla duygusal zekanın iş yaşamında bir iyi olma halini temsil eden iş performansına katkıda bulunabileceğini düşünmek çok da yanlış olmayacaktır.

\section{İş Performansı}

Her çalışanın işte beklenen performansı göstermesi hatta bu performansın da ötesine geçebilmesi tüm işletmeler için arzu edilen bir durumdur. Çalışanın istenilen performans seviyesinde işini yapamaması hem kendisi hem de örgüt için olumsuz sonuçlar doğurmaktadır. Konunun ele alınışında performansın nasıl tanımlandığ1 ve nasıl ölçüldügüne bağlı olarak değişen farklı bakış açıları söz konusudur. Genellikle iş performansı bir çalışanın örgüt tarafından belirlenen görevleri ne ölçüde yerine getirdiği ile alakalı bir olgu olarak görülmektedir. Ancak iş performansının belirli görevlerin yerine getirilmesinden daha fazlası olduğu ve çok çeşitli organizasyonel faaliyetleri içerdiği fikri, iş performansının anlaşılması ve ölçülmesi için önemlidir (Arvey ve Murphy, 1998, s. 162). İş performansı olarak işaret edilebilecek ve etiketlenebilecek tek bir sonuç, tek faktör veya tek bir olgu yoktur. İş performansı çok boyutlu bir kavramdır (Campbell, Mchenry ve Wise, 1990, s. 314).

Kavramın çok boyutlu olma özelliği yapılmış tanımlarında da kendini göstermektedir. İş performansı, bir bireyin standart bir süre boyunca gösterdiği münferit davranışlarının organizasyonu için toplam beklenen değeri olarak tanımlanmaktadır. Bu tanıma göre, performans belirli bir zaman dilimi içinde ortaya çıkan bir davranış özelliği olup, performansın atıfta bulunduğu davranışın özelliğinin organizasyon için beklenen bir değeri bulunmaktadır (Motowidlo ve Kell, 2012, s. 82). İş performansı, çalışanların dahil olduğu veya ortaya çıkardığ1, kurumsal hedeflerle bağlantılı olan ve bunlara katkıda bulunan ölçülebilir eylemler, davranışlar ve sonuçları ifade eder (Viswesvaran ve Ones, 2000, s. 216). Bir başka tanıma göre ise iş performansı, belirli bir süre boyunca belirli iş faaliyetlerini gerçekleştirmek için üretilen sonuçlar veya sergilenen davranışlardır (Bernardin ve Beatty, 1984, s. 12).

Bu tanımlarda iş performansına eylem, davranış ve sonuç açısından bakılmaktadır. Ancak Campbell'a (1990) göre performans, eylemin sonuçları veya çıktıları değildir; eylemin kendisidir. Kuşkusuz, bu ayrımı yapmak zordur çünkü davranış her zaman gözlemlenebilir değildir ve etkileri ile bilinebilir. Bununla birlikte, bilişsel davranışın bir sonucu olarak üretilen "çözümler", "ifadeler” veya "cevaplar”, performans olarak tanımlanabilecek eylemler olarak ele alınır. Campbell (1990) ayrıca iş performansinın yalnızca kuruluşun hedefleriyle ilgili eylemleri veya davranışları içerdiğini ifade etmiştir (Campbell, 1990, s. 704).

İş performansının ölçümlerinin hangi faktörlere dayanması gerektiğine dair birçok farklı görüş bulunmaktadır. Campbell ve diğerleri (1993), iş performansının doğası gereği çok boyutlu olduğunu ve işe has görev yeterliliği, işe has olmayan görev yeterliliği, yazılı ve sözlü iletişim görev yeterliliği, çaba göstermek, personel disiplinini korumak, iş arkadaşları ve takım performansına katkıda bulunmak, denetim/liderlik ve yönetim/idare olmak üzere sekiz faktörlü bir yapıdan oluştuğunu öne sürmüşlerdir (Campbell, McCloy, Oppler ve Sager, 1993, s. 46-48). İş performansını görev ve bağlamsal performans faktörleri diye gruplandıran çalışmalar (Motowidlo ve Scotter, 1994; Borman ve Motowidlo, 1993) da yer almaktadır. Görev performansı doğrudan görevleri yerine getirmeye etki eden faktörlerden oluşurken bağlamsal performans iş arkadaşlarına yardım etmek, örgütsel amaçları desteklemek ve örgütsel vatandaşlık davranışı gibi örgütsel etkinliğe katkıda bulunan ama görev performansı faktörleri içine de girmeyen eylemlerden oluşur. Bunlardan farklı olarak Waldman ve Spangler (1989) iş bilgisi ve yetenekler, çaba ve kaynaklar / kısıtlar gibi çalışma ortamına odaklanan entegre bir iş performansı modeli geliştirmiştir (Waldman ve Spangler, 1989, s. 47). Bu modeli diğerlerinden ayıran özellik bireysel iş performansına örgütsel faktörlerin de etkisini hesaba katarak bakmasıdır.

Hangi ölçütlerle tanımlanırsa tanımlansın iş performansı konusu sadece işletmeler için değil tüm örgütler için büyük bir meseledir. Çünkü iş yaşamındaki çoğu önlem ve iyileştirmenin temel olarak çalışanların performanslarını arttırmaya yönelik olduğu bilinmektedir (Develi, 2020). Bu yüzden çalışanların 
işlerini daha iyi yapmalarına imkân verecek olan her faktörün incelenmesi ve bu incelemede elde edilen sonuçlara göre hem bireyin hem örgütün faaliyette bulunması oldukça önemlidir.

\section{Araştırma Hipotezlerin Geliştirilmesi}

Çalışanların iş performansına etki eden en önemli faktörün bilişsel zekâları olduğu düşünülse de iş performansını tahmin etmek için tek başına bilişsel zekâya bakılması riskli olabilir çünkü düşük bilişsel zekaya sahip çalşanlar, yüksek duygusal zekaya sahiplerse etkili bir şekilde performans sergileyebilmektedirler (Côté ve Miners, 2006, s. 20). Dolaysıyla duygusal zekâsı yüksek düzeyde olan iş görenlerin işyerinde ve kişisel yaşamlarında daha yüksek başarılara ulaşmaları ve örgütlerin performansına önemli katkı sağlamaları beklenmektedir (Carmeli ve Josman, 2006, s. 413). Duygusal zekanın bir bireyin çalışma hayatının mesleki ve kariyer değerlendirmesi, iş performansı ve memnuniyeti ve mesleki stresle başa çıkabilmesi olmak üzere üç ana alanında önemli rol oynadığı düşünülmektedir (Matthews, Zeidner ve Roberts, 2002, s. 467).

Duygusal zekanın bu alanlardan biri olan performansla ilişkisi farklı örneklemlerde farklı ölçme araçları kullanan birçok çalışmada gösterilmiştir. Bu çalışmalarda performans bireysel, takımsal ve örgütsel olmak üzere farklı düzeylerde ele alınmıştır. Duygusal zekayı örgütsel performans ile ilişkilendiren çalışmalarda örgütün duygusal zekâsı çalışanlarının duygusal zekâ ortalamaları şeklinde tanımlanmıştır. $\mathrm{Bu}$ bağlamda literatürde örgütün duygusal zekâsı ile örgüt performansı (Kim, 2020; Boohene, Gyimah ve Osei, 2019; Menges ve Bruch, 2009) veya insan kaynaklar1 yöneticisinin duygusal zekâsı ile örgütün finansal performansı ile ilişkisini araştıran çalışmalara (Molina, Déniz-Déniz ve García-Cabrera, 2019) rastlanmaktadır. Genel sonuç örgütün duygusal zekâsı ile performansı arasında pozitif anlamlı ilişkiler bulunmasidir.

Literatürde ele alınan ikinci performans düzeyi takım bazında performanstır. Bu çalışmalarda duygusal zekanın takım performansına etkisi daha çok duygusal zekanın takım içindeki uyumu artırma ilişkisi üzerinden (Black, Kim, Rhee, Wang ve Sakchutchawan, 2019) (Rapisarda, 2002) tanımlanmıştır. Yine duygusal zekayı bilgi paylaşımına etkisi üzerinden takım performansı ile ilişkilendiren (Jamshed ve Majeed, 2019) veya takım performansını çeşitli ölçütlerle ele alıp duygusal zekanın buna etkisini araştıran çalışmalara (Rezvani, Barrett ve Khosravi, 2019; Feyerherm ve Rice, 2002) da rastlanmaktadır. Bu çalışmaların ortak sonucu takımdaki bireylerin duygusal zekalarının takımın performansı üzerinde olumlu bir etkisi olduğudur.

Son olarak literatürde duygusal zekâ ile bireysel olarak ele alınan iş performansı ilişkisini ortaya koymaya çalışan da birçok çalışma yer almaktadır. Bazılarında (Alferaih, 2017; Castillo ve Valle, 2017; Carmeli ve Josman, 2006; Côté ve Miners, 2006) duygusal zekâ doğrudan iş performansı ile ilişkilendirilmiş bazılarında ise (Kamassi, Boulahlib, Manaf ve Omar, 2021; Ashkanasy, Ashton-James ve Jordan, 2003) duygusal emek stratejileri gibi başka bir değişken üzerinden performansla dolayli bir şekilde ilişskilendirilmiştir. Çoğunlukla hizmet sektöründe yapılmış olan bu çalışmalarda da yine duygusal zekanın çalışanların bireysel iş performansları üzerinde anlamlı ve olumlu bir etkisi olduğu bulunmuştur. Benzer sonuca kamu sektöründe yapilan bir çalışmada (Shih ve Susanto, 2010) da ulaşılmıştır.

Görüldüğg̈ üzere birçok çalışma duygusal zekâ ile çalışanların bireysel pozitif yönlü ve iş performansı arasında bir ilişki olduğu sonucuna ulaşmıştır. Ancak duygusal zekâ veya duygusal zekanın bazı alt boyutları ile iş performansı arasında anlamlı bir ilişski bulamayan az sayıda birkaç çalışma (Gürbüz ve Yüksel, 2008; Austin, 2004; Day ve Carroll, 2004) olduğu da tespit edilmiştir.

Bu çalışmanın da örneklemini oluşturan çağrı merkezi çalışanları üzerinde yapılmış çalışmalara özel olarak değinmenin yararlı olacağı düşünülmektedir. Higgs (2004) İngiltere'deki iki finans ve bir kamu sektöründe yer alan toplam üç işletmede yedi boyutlu bir duygusal zekâ ölçeği kullanarak araştırmasını yürütmüş, işletmelerden aldığı toplam 289 çalş̧ana ait bireysel performans puanlarını 5 düzeyde kategorilendirmiştir. Nel ve Villiers (2004) tarafından yapılan çalışmanın örneklemini bir hayat sigortası şirketinde müşteri hizmetleri, satış ve idari ortamlarda çalışan 135 çağr1 merkezi temsilcisinden oluşturmaktadır. Ekip liderleri tarafindan doldurulan "Duygusal Yetkinlik Envanteri” bir ölçüm aracı olarak kullanılmış ve her bir katılımcı için genel bir iş performansı katılımcı kuruluş tarafından sağlanmıştır. İki çalışmanın da sonucu, çağrı merkezi ortamında duygusal zekâ ve iş performansı arasında istatistiksel olarak anlamlı ve pozitif bir ilişki olduğunu göstermektedir. Başka bir çalışmada Shamsuddin ve Rahman (2014) WLEIS ölçeğini kullanarak Malezya'da faaliyet gösteren iki çağnı merkezinde çalışan toplam 118 
çalışandan elde ettikleri verilerle duygusal zekanın iki boyutunun iş performansını artırdığını tespit etmişlerdir.

İlgili literatür incelendiğinde konu ile ilgili yapılmış olan çalışmaların önemli bir kısmının ulaştı̆̆ sonuç çalışanların duygusal zekâları ile iş performansları arasında anlamlı ve pozitif bir ilişki olduğudur. $\mathrm{Bu}$ bağlamda araştırmanın hipotezleri aşağıda sırasıyla verilmektedir:

$\mathrm{H}_{1}$ : Çalışanların kendi duygularını değerlendirebilmesi iş performanslarını pozitif yönde etkilemektedir.

$\mathrm{H}_{2}$ : Çalışanların başkalarının duygularını değerlendirebilmesi iş performanslarını pozitif yönde etkilemektedir.

$\mathrm{H}_{3}$ : Çalışanların duygularını düzenleyebilmesi iş performanslarını pozitif yönde etkilemektedir.

$\mathrm{H}_{4}$ : Çalışanların duygularını kullanabilmesi iş performanslarını pozitif yönde etkilemektedir.

\section{Yöntem}

Çalışma betimleyici araştırma tipine sahiptir. Araştırmanın analiz tekniği tümdengelim olup tarama modeli ilişskiseldir. Araştırma verileri açık uçlu sorular ve 5'li Likert Tipi derecelendirme ölçeği kullanılarak online anket yöntemiyle elde edilmiştir. Araştırma verilerinin analizinde SPSS 22.0 ve AMOS 23.0 istatistik programları kullanılmışır. Araştırma hipotezlerin test edilmesinde yapısal eşitlik modeli kullanılmışırı.

\section{Araştırmanın Amacı ve Önemi}

Bu çalışmanın amacı çağrı merkezi çalısanların duygusal zekâ düzeylerinin iş performansları üzerindeki etkisini tespit etmektir. Belirlenen araştırma amacı doğrultusunda duygusal zekâ; başkalarının duygularını değerlendirme, kendi duygularını değerlendirme, duyguların kullanımı, duyguların düzenlenmesi olmak üzere 4 alt boyutta ele alınacaktır. Literatürde kavramlar arası değișkenleri ele alan birçok ampirik araştırma bulunmaktadır. Bu araştırmalarda çalışanların performans ölçümünün, Likert tipi ölçekler vasıtasıyla gerçekleştirildiği görülmektedir. Diğer bir ifadeyle çalışan kendi performans değerlendirmesini kendisi yapmakta ve performans ölçümü algilanan performans düzeyinde belirlenmektedir. $\mathrm{Bu}$ araştırmada diğer birçok ampirik araştırma türlerinden farklı olarak, çalışanın örgüt tarafindan belirlenen ve çok yönlü objektif performans kriterlerine bağlı olarak elde edilen performans puanları kullanılarak analiz yapılmıştır. Araştırma bu yönüyle çalışanın kendi performansını değerlendirdiği araştırmalardan farklılaşarak somut iş performansı sonuçları üzerinde araştırma hipotezlerini test etme imkânı sağlamaktadır. Bu çalışmada, araştırma modeli çalışanların duygusal zekâ düzeylerinin iş performansları üzerinde etkisi test etmek üzere kurgulanmıştır. Çalışmanın araştırma modeli Şekil 1' de gösterilmektedir.

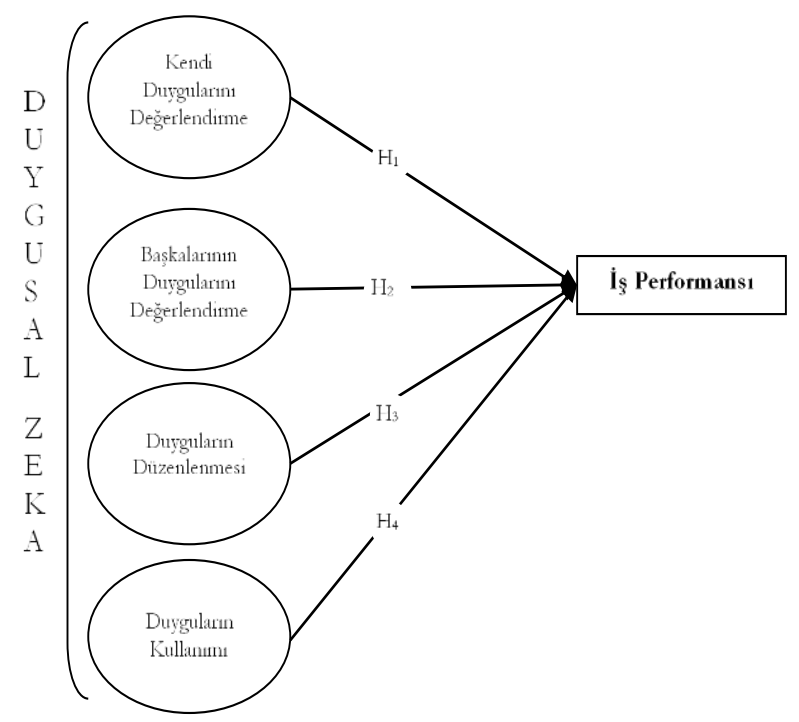

Şekil 1. Arastırma Modeli 


\section{Evren-Örneklem}

Araştırmanın evreni Ordu ilinde faaliyetlerine devam eden bir çağrı merkezinin tüm personelinden oluşmaktadır. Evren olarak belirlenen firma ulusal düzeyde faaliyet gösteren bir telekomünikasyon şirketinin iştiraki kuruluşu olarak faaliyet göstermektedir. Türkiye'nin birçok farklı bölgesinde faaliyet gösteren kurumsal yapıya sahip bir firma olarak faaliyetlerine devam etmektedir. Araştırma evrenini oluşturan çağrı merkezi 349 personele sahiptir. Tam sayı hedeflenerek yapılan araştırmada tüm çalışanlara anket formu online olarak gönderilmiş ve 219 personelden geri dönüş sağlanmıştır. Ulaşılan örneklem sayısının evreni temsil edip etmediğini belirlemek amacıyla, örneklem sayısının evren büyüklüğünü temsil kabiliyetini ölçen tabloya bakılmıştır. 0,95 güvenirlik ve 0,05 örneklem hatası ile evren büyüklüğünü temsil eden örneklem sayısına ilişkin sayılar göz önünde bulundurulduğunda 500 kişilik bir evren için 217 yeterli düzeye ulaşmış bir örneklem büyüklüğ̈ olarak kabul edilmektedir (Yazıcıoğlu ve Erdoğan, 2004). Bu noktadan hareketle 349 personelden oluşan bir evreni temsil etmek için 219 örneklem sayısının yeterli olduğunu söylemek mümkündür. Araştırmada çağnı merkezi çalışanlarının tercih edilmesinin çeşitli nedenleri bulunmaktadır. Çağrı merkezi çalışanları, çağrı merkezlerinin örgüt yapıları ve sağladıkları iş koşullarından dolayı örgütsel davranış alanında yapılan çalışmalarda sıklıkla yer almaktadır. Çağrı merkezi çalş̧anları hizmet sektörü içinde müşteriler ile direkt temas kurmakta ve müşteri şikâyetleri ve talepleri ile ilk etapta karşı karşıya kalmaktadır. İş koşulları yönüyle stresli bir iş ortamında yoğun vardiyalı mesailer yapmaktadırlar. Verilen resmi izinler doğrultusunda yaptıkları görüşmeler düzenli olarak kaydedilmektedir. Belirlenen satış hedeflerini ve şirket kampanyalarını verimli bir şekilde müşteriye sunmak zorunda kalmaktadırlar. Ayrıca belirli kriterler dahilinde kurum tarafından performans puanlamaları düzenli olarak izlenmektedir. Bu tespitlerden yola çıkarak çağrı merkezlerini, çalışma tarzı ve organizasyon yapısı yönüyle rutin çalışma şartlarına sahip ve iş yükünün yoğun olduğu iş yerleri olarak tanımlamak mümkündür (Keser, 2006). Bu açıdan personeller yoğun duygusal değişimler ile karşı karşıya kalabilmekte ve duyguların kullanımı, değerlendirilmesi ve düzenlenmesi büyük önem taşımaktadır. Bar-On’a göre de duygusal zekâ çalışanın performansı üzerinde doğrudan etkiye sahiptir. Kişi sahip olduğu duygusal zekâ düzeyine bağlı olarak iş hayatında karşlaştığı baskılara, hedef ve taleplerle başa çıkabilme yetisine sahip olabilmektedir (Bar-On, 2006). İfade edilen bu gerekçeler doğrultusunda duygusal zekâ ve iş performansı arasındaki ilişkinin test edilmesi için uygun bir örneklem olacağı düşüncesiyle çağrı merkezi çalşsanlanı tercih edilmiştir. Araştırma örneklemini oluşturan çalışanların demografik özelliklerini ortaya koyan bulgular Tablo 1' de sunulmaktadır.

Tablo 1. Araștrrma Örnekleminin Demografik Öz̨elliklerine Ilișskin Bulgular

\begin{tabular}{|c|c|c|c|c|c|c|c|}
\hline & & $F$ & $\%$ & & & $F$ & $\%$ \\
\hline \multirow{2}{*}{ Cinsiyet } & Erkek & 58 & 26,5 & \multirow{2}{*}{ Medeni Durum } & Evli & 69 & 31,5 \\
\hline & Kadin & 161 & 73,5 & & Bekâr & 150 & 68,5 \\
\hline \multirow{4}{*}{ Yaş } & $18-24$ & 67 & 30,6 & \multirow{3}{*}{$\begin{array}{l}\text { Kurum } \\
\text { Tecrübesi }\end{array}$} & 1 yildan az & 78 & 35,6 \\
\hline & $25-29$ & 86 & 39,3 & & $1-5 \mathrm{y} 1 \mathrm{l}$ & 73 & 33,4 \\
\hline & $30-34$ & 40 & 18,3 & & 5 yildan fazla & 68 & 31,1 \\
\hline & 35 ve üzeri & 26 & 11,9 & \multirow{4}{*}{ Sektör Tecrübesi } & 1 yildan az & 71 & 32,4 \\
\hline \multirow{3}{*}{$\begin{array}{l}\text { Eğitim } \\
\text { Düzeyi }\end{array}$} & Lise & 63 & 28,8 & & $1-5 \mathrm{yll}$ & 78 & 35,6 \\
\hline & Ön Lisans & 92 & 42,0 & & 5 yildan fazla & 70 & 32,0 \\
\hline & Lisans ve Lisansüstü & 64 & 29,2 & & & & \\
\hline
\end{tabular}

Tablo 1'den elde edilen veriler incelendiğinde çağrı merkezleri çalışanların çoğunluğunun kadın personellerden oluştuğu $(\% 73,5)$ görülmektedir. Yapılan birçok araştırmada diksiyon ve telaffuz gibi nedenlerle firmaların çağrı merkezlerinde çoğunlukla kadın çalışanları istihdam ettikleri görülmüştür (Keser, 2006) Araştırma bulguları da bu durumu desteklemektedir. Çalışanların eğitim seviyesi yönüyle ağırlıklı olarak ön lisans düzeyinde yer aldığı (\%42) görülmektedir. Son olarak kurum tecrübesi ve sektör tecrübesi arasında kategorilerin benzer yüzdelik oranlara sahip olduğu görülmektedir. Bu durum çalışanların büyük bir çoğunluğunun sektör tecrübesini halihazırda çalıştığı işletmede kazandığ1 söylenebilir.

\section{Veri Toplama Araçları}

Çalışmada verilerin elde edilmesinde online anket formu kullanılmıştır. Araştırma verileri şirket personelinin kurumsal e-posta adreslerine gönderilen anket formu vasıtasılyla elde edilmiştir. Araştırma anket formunda yer alan duygusal zekâ ölçek ifadeleri 5'li Likert Tipi derecelendirme ölçeğine göre oluşturulmuştur. Anket formunun ilk bölümünde demografik özellikler dahilinde çalışanların cinsiyet, eğitim durumu, medeni durumu, yaşı, kurumdaki çalışma süresi ve sektördeki çalısma süresini belirlemeye 
yönelik ifadeler yer almıştır. Anket formunun ikinci bölümünde çalışanların kurumsal performans puanını tespit etmeye yönelik bir soru ve duygusal zekâ ölçeği yer almıştır. Çalışmanın bu bölümünde araştırma örneklemini oluşturan işletmenin performans değerlendirme kriterleri çerçevesinde oluşturduğu performans puanlama yöntemine ve araştırmada kullanılan duygusal zekâ ölçeğine ilişkin temel bilgilere, yapılan geçerlilik ve güvenilirlik analiz sonuçlarına yer verilmektedir.

İs Performansınn Ölçümü: Araştırmada çalışanların bireysel iş performanslarını ölçmek amacıyla kurumları tarafindan ilan edilen aylık performans puanları kullanılmışır. Çalışanların performans puanları son altı aylık ortalamaları sorularak tespit edilmiştir. Bu durum uzun dönemli bir performans değerlendirmesi yapılarak personelin ortalama performans düzeyinin tespit edilmesine imkân sağlamaktadır. Kurumda personelin iş performans1, objektif ve ölçülebilir kriterler çerçevesinde oluşturulmuş bir puanlama sistemi ile belirlenmektedir. Her bir personelin performans puanı aylık olarak çalışana bildirilmektedir. $\mathrm{Bu}$ kriterler ve puan ağırlıkları Tablo 2' de sunulmaktadır.

Tablo 2. Performans Puanlama Kriterleri ve Puan Ağrllklar

\begin{tabular}{|c|c|c|}
\hline Kriterler & Açıklama & $\begin{array}{l}\text { Kriter Performans } \\
\text { Puanı }\end{array}$ \\
\hline Çağrn Hizmeti Kalitesi & $\begin{array}{l}\text { Kalite standartları gereğince performans ve iş süreci değerlendirmesi için } \\
\text { belli sayıda çağrı dinlenir ve puanlama yapılır. Çağrı sayısı } 5 \text { ya da daha } \\
\text { fazla olabilir. Puanlama } 0 \text { ile } 100 \text { arasında olur. Elde edilen puanın } \\
\text { ortalaması alınır. }\end{array}$ & +33 \\
\hline $\begin{array}{l}\text { Konuşma Süresi } \\
\text { Hedefini Sağlamak }\end{array}$ & Müşteri ile konuşulan süre (çağrı süresi) hedefini sağlamak & +30 \\
\hline Kayıt Başarısı & $\begin{array}{l}\text { Müssteri talepleri, arıza ve şikâyet bildirimlerinin doğru olarak kayıt altına } \\
\text { alınması }\end{array}$ & +15 \\
\hline İşe Devamlılık & $\begin{array}{l}\text { Personelin düzenli olarak işe devam etmesi, sağlık ve mazeret izinlerinin } \\
\text { s1k kullanılmaması }\end{array}$ & +5 \\
\hline $\begin{array}{l}\text { Eksik Çalışma Süresinin } \\
\text { Olmaması }\end{array}$ & $\begin{array}{l}\text { Personelin çalış̧ma saatleri içinde elektrik kesintisi ya da sistem sorunu } \\
\text { nedeniyle yaşadığı eksik çalışma durumunu ileri bir tarihte telafi etmesi }\end{array}$ & +5 \\
\hline $\begin{array}{l}\text { Kısa Mola Sürelerine } \\
\text { Uyum }\end{array}$ & 30 dakikalık kısa mola sürelerine uyum & +3 \\
\hline $\begin{array}{l}\text { Yemek Molas1 } \\
\text { Sürelerine Uyum }\end{array}$ & 30 dakikalık yemek molası sürelerine uyum & +3 \\
\hline Vardiya Uyumu & Personelin belirlenen vardiya başlangıç ve bitiş saatlerine riayet etmesi. & +3 \\
\hline Günlük Sinav & $\begin{array}{l}\text { Çalışılan her gün için } 3 \text { sorudan oluşan bir test, aylık not ortalaması } 80 \text { ve } \\
\text { üzeri tam puan }\end{array}$ & +2 \\
\hline Aylik Sinav & 10 sorudan oluşan genel maksatlı sorular, 80 ve üzeri tam puan & +1 \\
\hline Müşteri Şikâyeti & $\begin{array}{l}\text { Müşterinin belirli kanallar (çağrı merkezi ya da online işlem) üzerinden } \\
\text { görüştügü kişiyi şikâyet etmesi }\end{array}$ & $(-6),(-10),(-20)$ \\
\hline Müşteri Teşekkürü & $\begin{array}{l}\text { Çağr1 merkezi personelinin görüştüğü müşterinin sunulan hizmetten çok } \\
\text { memnun kalması durumunda üst yetkililer tarafindan çağrının } \\
\text { dinlenmesini istemesi }\end{array}$ & $(+1)$ \\
\hline
\end{tabular}

Örneklem grubunda yer alan her bir çağrı merkezi çalş̧anın performansı Tablo 2'de görülen kriterler doğrultusunda elde ettiği puanlar sonucunda oluşmaktadır. Müşterilerin muhatap olduğu temsilci hakkında kuruma ilettiği teşekkür ve şikayetler de çalışanların bireysel performans değerlendirmesinde yer almaktadır. Müşteri temsilcisi her bir müşteri teşekkürü için +1 puan almaktadır. Buna karşın müşteri şikayetinde ise şikâyete konu olan durumun önem derecesine göre personel $-6,-10$ ve -20 puanlar alabilmektedir. Performans puanlama sistemine örnek olması ve konunun daha iyi anlaşılabilmesi için örneklem grubunda yer alan iki müşteri temsilcisinin bir aylkk performans puanları Tablo 3' te sunulmuştur. 
Tablo 3. Çăgr Merkęi Personeli Örnek Puanlama Tablolar

\begin{tabular}{|c|c|c|c|c|c|}
\hline Kriterler & $\begin{array}{l}\text { Kriter } \\
\text { Puanı }\end{array}$ & $\begin{array}{l}\text { Kazanilan } \\
\text { Puan }\end{array}$ & Kriterler & $\begin{array}{l}\text { Kriter } \\
\text { Puanı }\end{array}$ & $\begin{array}{c}\text { Kazanılan } \\
\text { Puan }\end{array}$ \\
\hline Çağnn Hizmeti Kalitesi & 33 & 33 & Çağn1 Hizmeti Kalitesi & 33 & 33 \\
\hline $\begin{array}{l}\text { Konuşma Süresi Hedefini } \\
\text { Sağlamak }\end{array}$ & 30 & 30 & $\begin{array}{l}\text { Konuşma Süresi Hedefini } \\
\text { Sağlamak }\end{array}$ & 30 & 30 \\
\hline Kayıt Başarısı & 15 & 15 & Kayıt Başarısı & 15 & 15 \\
\hline İşe Devamlılık & 5 & 5 & İşe Devamlilık & 5 & 5 \\
\hline $\begin{array}{l}\text { Eksik Çalışma Süresinin } \\
\text { Olmaması }\end{array}$ & 5 & 5 & $\begin{array}{l}\text { Eksik Çalışma Süresinin } \\
\text { Olmaması }\end{array}$ & 5 & 5 \\
\hline $\begin{array}{l}\text { Kısa Mola Sürelerine } \\
\text { Uyum }\end{array}$ & 3 & 3 & $\begin{array}{l}\text { Kisa Mola Sürelerine } \\
\text { Uyum }\end{array}$ & 3 & 3 \\
\hline $\begin{array}{l}\text { Yemek Molası Sürelerine } \\
\text { Uyum }\end{array}$ & 3 & 3 & $\begin{array}{l}\text { Yemek Molası Sürelerine } \\
\text { Uyum }\end{array}$ & 3 & 3 \\
\hline Vardiya Uyumu & 3 & 3 & Vardiya Uyumu & 3 & 3 \\
\hline Günlük Sınav & 2 & 2 & Günlük Sınav & 2 & 2 \\
\hline Aylik Sinav & 1 & 1 & Aylik Sinav & 1 & 1 \\
\hline Müşteri Şikâyeti & -6 & -6 & Müşteri Şikâyeti & $-6,-10$ & -16 \\
\hline \multirow[t]{2}{*}{ Müşteri Teşekkürü } & +1 & +1 & Müşteri Teşekkürü & & 0 \\
\hline & TOPLAM & 95 & & TOPLAM & 84 \\
\hline
\end{tabular}

Tablo 3' te görüldüğü üzere örnek olarak seçilen her iki çağrı merkezi personeli tüm kriterleri sağlamıştır. Bununla birlikte bir müşteri teşekkürü ve bir müşteri şikâyeti alan personelin aylık performans notu 95 puan olurken iki müşteri şikâyeti alan personelin aylık performans notu 84 olarak belirlenmiştir.

Araştırma örnekleminde yer alan tüm çalışanların performans puan ortalaması 10 ile 110 arasında değişmektedir. Şirket yöneticileri ile yapılan görüşmeler neticesinde çalışan performans puanları belirli puan aralıkları dahilinde değerlendirildiği belirlenmiştir. Buna göre (0-54) performans puana sahip personel başarısız, (55-74) puan arağından yer alan personel orta düzey performansa sahip, 75 ve üzeri performansa sahip personel ise başarılı olarak kabul edilmektedir. Kurumun performans düzeylerine göre belirlediği performans puan aralıkları, performans puan aralığında yer alan personel sayısı Tablo 4' te sunulmaktadır.

Tablo 4. Calssanlarn Performans Puan Aralıklar ve Performans Düzeylerine Yönelik Frekans Analizi Sonuçar

\begin{tabular}{|c|c|c|c|}
\hline $\begin{array}{c}\text { Performans Puan } \\
\text { Aralığ1 }\end{array}$ & Performans Düzeyi & $\begin{array}{l}\text { Performans Düzeyinde Yer Alan Personel } \\
\text { Sayısı }\end{array}$ & Kategori \\
\hline$(0-54)$ & Başarısız Performans & 38 & 1 \\
\hline$(55-74)$ & Orta Düzey Performans & 105 & 2 \\
\hline (75 ve üzeri) & Başarılı Performans & 76 & 3 \\
\hline
\end{tabular}

Araştırmada iş performansının yapısal eşitlik modelinde test edilmesi için çalışanların performans puanları, şirketin performans düzeyi için belirlediği puan aralıkları baz alınarak kategorilendirilmiştir. Bu sınıflama neticesinde başarısız performans düzeyinde yer alan çalışanlar ' 1 ', orta düzey performansa sahip çalışanlar '2', başarılı performans düzeyine sahip çalışanlar '3' olarak kodlanmıştır.

Duygusal Zekâ Ölçeği: Çalışmada Wong ve Law (2002) tarafindan oluşturulan Duygusal Zekâ Ölçeği (WLEIS) kullanılmıştır. Ölçekte başkalarının duygularını değerlendirme, kendi duygularını değerlendirme, duyguların düzenlenmesi ve duygularının kullanımı olmak üzere toplam dört alt boyut bulunmaktadır. Ölçek toplam 16 ifadeden oluşmakta ve her bir boyutun ölçümü için dört ifade yer almaktadır. Ulusal yazında örgütsel davranış araştırmalarında duygusal zekâ ölçümü için en sık kullanılan ölçeklerden biridir. Yapılan araştırmalarda ölçeğin orijinal yapısına uygun yap1 geçerliliği sonuçları verdiği tespit edilmiştir. Ayrıca araştırmalarda ölçek ve alt boyutları yüksek güvenilirlik katsayılarına ulaşmıştır (Dirican, 2013; Özbezek ve Paksoy, 2017; Turhan ve Çetinsöz, 2019; Kapusuz, 2019). Araştırmada duygusal zekâ ölçeğinin yapı geçerliliğini ortaya koymak amacıyla doğrulayıcı faktör analizi (DFA) yapılmıştır. Yapılan analizler sonucunda ölçeğin dört faktörlü yapısına uygun bir dağılım gösterdiği belirlenmiştir. Şekil 2'de duygusal zeka ölçeğinin yapı geçerliliğini ortaya koyan yapısal eşitlik modeli sunulmaktadır. 


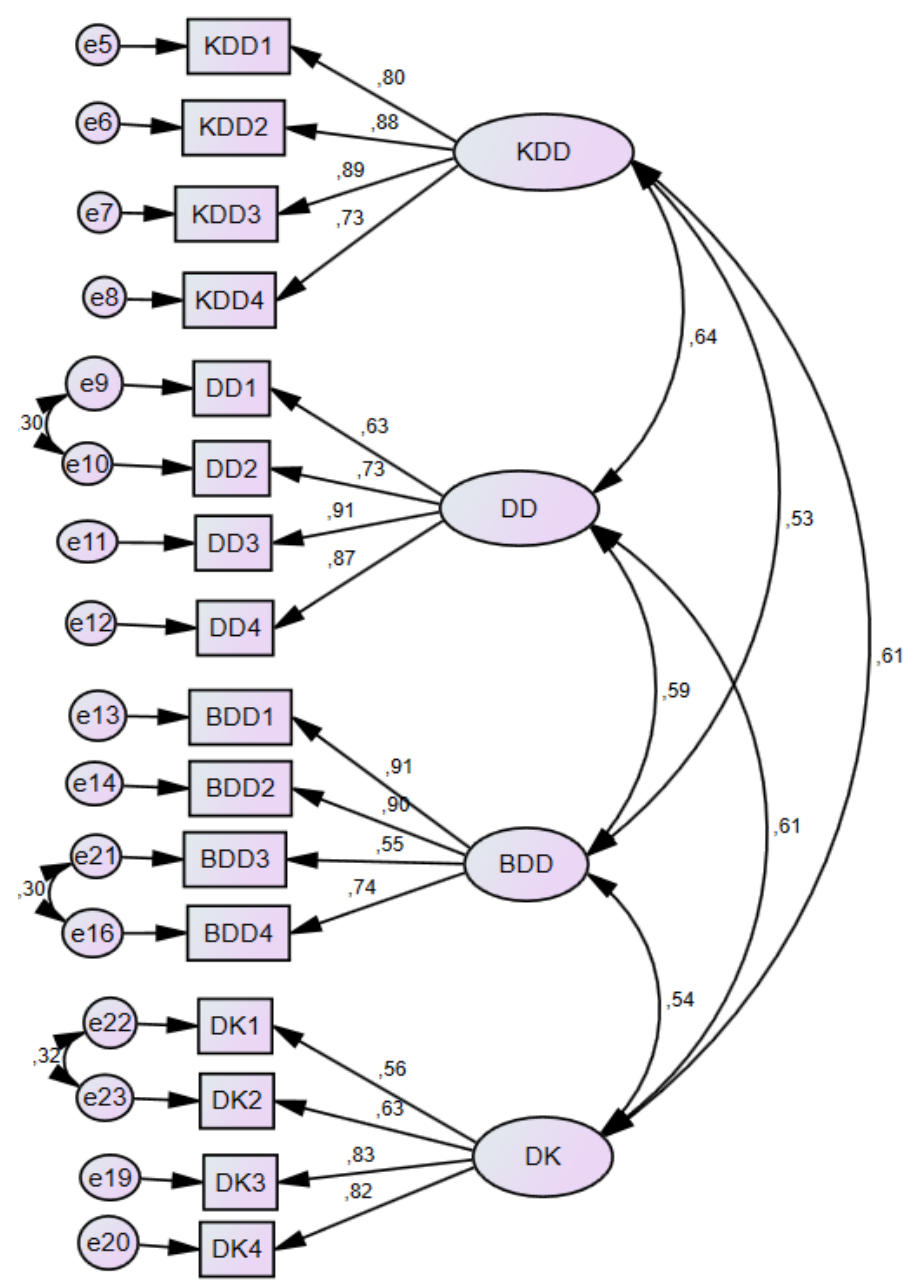

Şekil 2. Duygusal Zekâ Ölçeğine Ait Doğrulayıı Faktör Analiæi Sonuclar

Şekil 2'de elde edilen bulgular temelinde modelin uyum iyiliği değerlerini yükselten 3 iyileştirme (modifikasyon) yapılmıştır. Modelde yer tüm ifadelerin faktör yükleri 0,50 'nin üzerinde olduğu belirlenmiştir. Modelin p<0,01 anlamll1k düzeyinde x2/df: 2.529, RMSEA: 0,078, NFI: 0,907, IFI; 0,935, GFI: 0,886 değerlerine sahiptir. Bu sonuçlara ölçeğe ait modelin uyum iyiliğinin kabul edilebilir uyum ve iyi uyum değerlerine sahip olduğu ortaya konmuştur. Ölçek boyutlarına ait Cronbach Alfa iç tutarlıllk katsayıları, başkalarının duygularını değerlendirme: 0,863 ; kendi duygularını değerlendirme: 0,892; duyguları kullanımı:0,792; duyguların düzenlenmesi 0,865 olarak tespit edilmiştir. Bu sonuçlar duygusal zekâ ölçeğinin alt boyutlarının Croanbach Alfa iç tutarlılık katsayılarının yüksek güvenilirlik düzeyde yer aldığını ortaya koymaktadır.

\section{Bulgular}

Çalışmada ilk olarak araştırma modelinde yer alan örgütsel değişkenler arasında ilişkiler tespit edilecektir. Bu doğrultuda yapılan doğrulayıcı faktör analizi neticesinde geçerlilikleri tespit edilen başkalarının duygularını değerlendirme, kendi duygularını değerlendirme, duyguların kullanımı ve duyguların düzenlenmesi duygusal zekâ alt boyutları ile çalışanların iş performansı arasındaki ilişkiler korelasyon analizi ile test edilmiştir. Yapılan analiz sonuçları Tablo 5 'te sunulmaktadır.

Tablo 5. Arastrma Değişkenlerine Ait Korelasyon Analizi

\begin{tabular}{|c|c|c|c|c|c|}
\hline & KDD & DD & BDD & DK & İş Performans1 \\
\hline KDD & 1 & & & & \\
\hline DD &, $571 * *$ & 1 & & & \\
\hline BDD &, $505^{* *}$ &, $505^{* *}$ & 1 & & \\
\hline DK &, $514 * *$ & $458^{* *}$ &, $458^{* *}$ & 1 & \\
\hline İş Performansı & 005 &, 119 & ,117 & ,201** & 1 \\
\hline
\end{tabular}

"korelasyon $\mathrm{p}<0,001$ düzeyinde anlamlı (KDD: Kendi Duygularını Değerlendirme, BDD: Başkalarını Duygularını Değerlendirme, DD:

Duyguların Düzenlenmesi, DK: Duyguların Kullanımı) 
Tablo 5'ten elde edilen verilere bakıldığında duygusal zekanın alt boyutlarından sadece duyguların kullanımı ile iş performansı arasında (r: ,201) düzeyinde pozitif yönlü anlamlı bir ilişki olduğu tespit edilmiştir. Elde edilen bu sonuçlar temelinde korelasyon ilişkisi tespit edilemeyen başkalarının duygularını değerlendirme, duyguların düzenlenmesi, kendi duygularını değerlendirme boyutları yapısal eşitlik modelinden çıkarılmıştır.

$\mathrm{Bu}$ aşamadan sonra duyguların kullanım düzeyi ile iş performansı arasındaki ilişki yapısal eşitlik modeli ile test edilmiştir. Şekil 3' de gösterilen yapısal eşitlik modelinde duyguların kullanım düzeyi gizil değişken, iş performansı ise gözlemlenen değişken olarak yer almışırı.

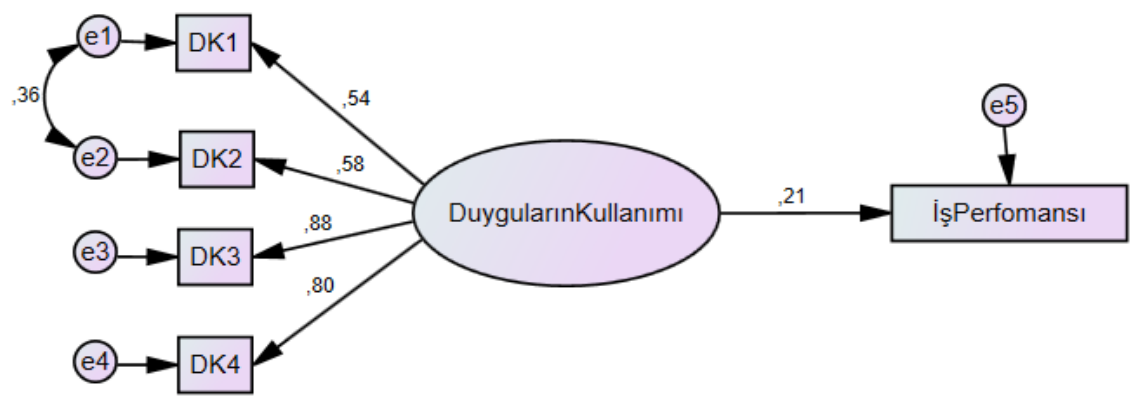

Şekil 3. Araștrma (Nibai) Modeli

Yapılan analizler neticesinde araştırma modelinin uyum iyiliği değerlerini yükselten bir modifikasyon(iyileştirme) gerçekleştirilmiştir. Modelin uyum iyiliği indeks değerlerinin $\mathrm{p}<0,001$ anlamllık düzeyinde (x2/df: 3,563; RMSEA: 0,78; NFI: 0,960; CFI: 0,969; GFI: 0,975) kabul edilebilir uyum ve iyi uyum değerlerine sahip olduğu belirlenmiştir. Araştırma modelinde test edilen yola ilişkin bulgular Tablo 6' da gösterilmektedir.

Tablo 6. Araşttrma Modeline Ait Yolun Regresyon Ağrrluğa

\begin{tabular}{ccccc}
\hline Test Edilen Yol & & $\begin{array}{c}\text { Standardize Edilmiş } \\
\text { Regresyon Ağırlığ }\end{array}$ & (p) \\
\hline Duyguların Kullanımı & $\rightarrow$ & İş Performansı & 0,212 & 0,005 \\
\hline
\end{tabular}

Tablo 6 incelendiğinde duyguların kullanım düzeyinden iş performansı üzerindeki etkisini tespit etmek amaciyla oluşturulan yolun $\mathrm{p}<0,005$ anlamll1k düzeyinde $(0,212)$ standardize edilmiş regresyon ağırlığına sahip olduğu ortaya konmuştur.

\section{Tartışma, Sonuç ve Öneriler}

Duygusal zekâ kavramı son yıllarda hem örgütsel davranış alanında hem de insan kaynakları alanında oldukça fazla dikkat çeken bir konu olmuştur. Duygular, insanların çevrelerinde gerçekten neler olup bittiğine dair onları uyaran uyarı sistemleridir. Bir yandan fizyolojik değişiklikler, diğer yandan da psikolojik değişiklikler içeren insan zihninin karmaşık bir durumudur (Singh, 2006, s. 30). Duyguların bu karmaşık doğası duygusal zekâ kavramının da net olarak tanımlanmasını zorlaştırmaktadır. En yaygın kabul gören bilimsel tanımına göre duygusal zekâ (Zeidner, Matthews ve Roberts, 2004, s. 373) kişinin kendi ve başkalarının duygularını izleme, bunlar arasında ayrım yapma ve bilgiyi kişinin düşüncelerini ve eylemlerini yönlendirmek için kullanma becerisi olarak tanımlanmaktadır (Salovey ve Mayer, 1990, s. 189). Tanım incelendiğinde duygusal zekanın hayatın her alanında ihtiyaç duyulan bir zekâ türü olduğu görülebilir. Kişinin yaşamının önemli bir alanını işgal eden iş hayatında çalışan, duygusal zekasını kullanacak ve bu durum işini yapma şeklini ve bunun örgüte yansıması olan iş performansını da doğrudan etkileyebilecektir. İş performansı en genel anlamda bir bireyin standart bir süre boyunca gerçekleştirdiği ayrı ayrı davranışların organizasyon için toplam beklenen değeri olarak tanımlanmaktadır (Motowidlo ve Kell, 2012, s. 82). Kişi duygusal zekasını kullanarak davranış gösterecek ve gösterdiği bu davranışların toplamı örgütün bekledikleri ile karşılaştırılacaktır. Bu karşılaşıtırmada beklentinin gerçekleştirilmesi veya aşılması çalışanın iyi performans gösterdiği şeklinde yorumlanırken beklentinin altına kalması performansının iyi olmadığını düşündürecektir.

Bu çalışmada çalışanın duygusal zekasının iş performansına etki ettiği varsayımı test edilmeye çalışılmıştır. Bu çabada örneklem olarak çağrı merkezi çalışanları seçilmiştir ki bunun sebebi yaptıkları işin 
doğasının, duygusal zekâ kullanımını fazlasıyla gerektirecek nitelikte olduğu düşüncesidir. Araştırma verilerinden elde edilen bulgulara göre başkalarının duygularını değerlendirme, kendi duygularını değerlendirme ve duyguların düzenlenmesi duygusal zekâ alt boyutları ile iş performansı arasında anlamlı bir ilişsi tespit edilememiştir. Bu sonuç temelinde $\mathrm{H}_{1}, \mathrm{H}_{2}$ ve $\mathrm{H}_{3}$ hipotezleri desteklenmemektedir. Yapılan korelasyon analizi soncunda aralarında pozitif yönlü anlamlı ilişki tespit edilen duyguların kullanımı alt boyutu ile iş performansı arasındaki ilişki yapısal eşitlik modeli ile test edilmiştir. Yapılan analiz sonucunda çalışanların duyguların kullanım düzeyinin iş performansı üzerinde pozitif yönlü anlamlı bir etkiye ( $\beta: 212)$ sahip olduğu tespit edilmiştir. Bu sonuçlara göre $\mathrm{H}_{4}$ desteklenmektedir. Literatürde WLEIS ölçeğini kullanarak duygusal zekâ ile iş performansı arasındaki ilişkiyi açıklamaya çalışan birçok çalışma incelendiğinde örneklem özelliklilerine ve iş performansının ölçüm şekline bağlı olarak sonuçların çeşitlilik gösterdiği görülmektedir. Örneğin öğretmenler üzerinde yapılan bir çalışmada (Yoke ve Panatik, 2015) duygusal zekanın tüm boyutlarının iş performansı ile ilişkisi anlamlı bulunurken, yine bu çalışmanın da örneklemini oluşturan çağrı merkezi çalışanlarından elde edilen verilerle yapılan bir çalışmada (Shamsuddin ve Rahman, 2014) kendi duygularını değerlendirme hariç diğer boyutların işe performansı ile ilişkisi anlamlı bulunmuştur.

Duyguların kullanımı boyutu bireylerin duygularını yapıcı faaliyetlere ve kişisel performansa yönlendirerek onları kullanma yetenekleriyle ilgilidir (Wong ve Law, 2002, s.246). Duygusal zekâ yönüyle duygularını olumlu olarak yönlendirebilen (kullanabilen) çalışanlar, kendilerini yetenekli bir kişi olduğu yönünde motive etmekte, geleceğe yönelik hedefler belirlemekte ve bu belirli bu hedefi başarmak içinden ellerinden gelenin en iyisini yapmaya çalışmaktadır. Bu boyutun hemen hemen her sektördeki çalışanın iş performansını etkilemesi doğaldır çünkü kişinin kendine inanması, bir amacının olması ve kendisini bu amaca yönlendirmesi büyük bir avantaj sağlamaktadır.

$\mathrm{Bu}$ çalışmada esasında gerek ilgili literatür incelemesi sonucunda elde edilen bilgiler gerekse örneklemin müşteri ile doğrudan ilişki içinde olan hizmet sektörü çalışanları olması nedeniyle tüm duygusal zekâ boyutlarının çalıssan performanslarına etki etmesi beklenmekteydi. Bu noktada araştırma sonuçlarının belirli düzeyde ilgili literatürden farklılaştı̆̆ sonucu ortaya çıkmaktadır. Fakat bu araştırmada diğer ampirik araştırmalardan farklı olarak, iş performansının ölçümüne ait verilerin elde edilmesinde bireylerin kendilerini değerlendirdiği ve Likert tipi derecelendirme ölçeği kullanılan yöntem yerine, objektif kriterler çerçevesinde belirlenmiş performans puanları kullanılmıştır. $\mathrm{Bu}$ durumun araştırma sonuçlarını diğer araştırmalardan farklılaştırdığı düşünülmektedir.

Araştırma sonuçlarından elde edilen bulgular doğrultusunda hem araştırmacılara hem de alan uygulayıcılarına yönelik çeşitli öneriler sunulmaktadır. Bundan sonraki yapılacak araştırmalar kurumsal performans puanlama sistemlerinin var olduğu bir örgütte gerçekleştiriliyorsa iş performansının ölçümünde Likert tipi derecelendirme ölçekleri yerine belirli bir zaman periyodu dahilinde tespit edilen iş performans puanlarının kullanılması önerilmektedir. Çalışmanın araştırma sonuçlarından değinildiği üzere iş performansının, performans puanları ile ölçülmesi sonucunda ilgili literatürden farklılaştı̆̆ı sonucu öngörülmektedir. Bu durumun iş performans puanlarının objektif kriterler çerçevesinde ölçüldügü farklı çağrı merkezi örneklemlerinde ve farklı iş sektörlerinde (bankacilık sektörü, sağlık sektörü vb.) test edilmesinin araştırma sonuçlarında ifade edilen varsayımın sağlam bir zemine oturmasına imkân tanıyacaktır. Kavramlar arası ilişkiyi ele alacak araştırmalarda, araştırma modelinin aracı ve düzenleyici role sahip olabilecek örgütsel değişkenler ile kurgulanmasının çalışmalara derinlik kazandıracağı düşünülmektedir. Araştırma bulgularından elde edilen sonuçlara göre çalışanların duygularını kullanma düzeyi iş performanslarını olumlu yönde etkilemektedir. Bu noktada öncelikle firma üst yönetiminin iş mülakatlarında geleceğe yönelik hedefler belirleyebilen ve duygularını olumlu yönlendirebilen adayları tercih etmesi firmaya avantaj sağlayacaktır. Ayrıca üst yönetici ve özellikle çağnı merkezi çalışanlarının ilk düzey yöneticisi konumunda olan takım liderlerinin çalş̧anların öz yeterlik ve öz yetkinliğini artırmaya yönelik girişimlerde bulunması, haftalık ve aylık performans hedeflerinin sağlanması adına çalışanları motive etmeleri gerekmektedir. Diğer bir ifadeyle çağrı merkezi çalışanlarının duygularını kullanmaları, (harekete geçirmeleri) noktasında destek olmaları önem arz etmektedir.

Araştırma birçok ampirik araştırmada olduğu çeşitli temel kısıtlara sahiptir. Bu araştırma zaman ve mekân kısıtı nedeniyle sadece çağrı merkezi çalsşanları üzerinde gerçekleştirilmiştir. Ayrıca araştırma örneklemi ulusal düzeyde faaliyet gösteren kurumsal bir firmanın sadece bir çağnı merkezinden oluşmaktadır. Bu nedenle çalışma bulguları sadece kısıtlı olan araştırma evrenini temsil etmektedir. 


\section{Etik Beyan}

"Daha İyi Bireysel İş Performansı Arayışında Duygusal Zekanın Etkisinin Test Edilmesi" başlıklı çalışmanın yazım sürecinde bilimsel kurallara, etik ve alıntı kurallarına uyulmuş; toplanan veriler üzerinde herhangi bir tahrifat yapılmamış ve bu çalışma herhangi başka bir akademik yayın ortamına değerlendirme için gönderilmemiştir. Gerekli olan etik kurul izinleri Tokat Gaziosmanpaşa Üniversitesi Sosyal ve Beşerî Bilimler Araştırmaları Etik Kurulu’nun 02.04.2021 tarih ve 07 sayılı toplantısında alınmıştır.

\section{Kaynakça}

Alferaih, A. (2017). Conceptual model for measuring Saudi banking managers' job performance based on their emotional intelligence (EI). International Journal of Organizational Analysis, 25(1), 123-145. doi:10.1108/IJOA-102014-0807

Arvey, R. D. ve Murphy, K. R. (1998). Performance evaluation in work settings. Annual Review of Psychology, 49(1), 141-168. doi: 10.1146/annurev.psych.49.1.141

Ashkanasy, N. M. ve Daus, C. S. (2002). Emotion in the workplace: The new challenge for managers. Academy of Management Executive, 16(1), 76-86. doi: 10.5465/AME.2002.6640191

Ashkanasy, N. M., Ashton-James, C. E. ve Jordan, P. J. (2003). Performance impacts of appraisal and coping with stress in workplace settings: The role of affect and emotional intelligence. In P. Perrewe, ve D. Ganster (Eds.), Emotional and Physiological Processes and Positive Intervention Strategies (Research in Occupational Stress and Well Being, Vol. 3) (pp. 1-43). Bingley: Emerald Group Publishing Limited.

Austin, E. J. (2004). An investigation of the relationship between trait emotional intelligence and emotional task performance. Personality and Individual Differences, 36(8), 1855-1864. doi: 10.1016/j.paid.2003.07.006

Bar-On, R. (2000). Emotional and social intelligence: Insights from the Emotional Quotient Inventory In R. Bar-On, ve J. D. A. Parker (Eds.), The handbook of emotional intelligence: The theory and practice of development, evaluation, education, and application-at home, school, and in the workplace (pp. 363-388). San Fransisco: Jossey-Bass.

Bar-On, R. (2006). The Bar-On model of emotional-social intelligence. Psicothema, 18, 13-25. Erişim Adresi: http://www.psicothema.com/pdf/3271.pdf

Bar-On, R. (2010). Emotional intelligence: an integral part of positive psychology. South African Journal of Psychology, 40(1), 54-62. doi: 10.1177/008124631004000106

Bernardin, H. J. ve Beatty, R. W. (1984). Performance appraisal: Assessing human behavior at work. California: Kent Publishing.

Black, J., Kim, K., Rhee, S., Wang, K., ve Sakchutchawan, S. (2019). Self-efficacy and emotional intelligence: Influencing team cohesion to enhance team performance. Team Performance Management, 25(1/2),100-119. doi: 10.1108/TPM-01-2018-0005.

Boohene, R., Gyimah, R. A. ve Osei, M. B. (2019). Social capital and SME performance: The moderating role of emotional intelligence. Journal of Entrepreneurship in Emerging Economies, 12(1), 79-99. doi: 10.1108/JEEE-102018-0103

Borman, W. C. ve Motowidlo, S. J. (1993). Expanding the criterion domain to include elements of contextual performance. In N. Schmitt, ve W. C. Borman (Eds.), Personnel Selection in Organizations (pp. 71-98). New York: Wiley.

Campbell, J. P. (1990). Modeling the performance prediction problem in industrial and organizational psychology. In M. D. Dunnette, ve L. M. Hough (Eds.), Handbook of industrial and organizational psychology (pp. 687-732). California: consulting psychologistic press.

Campbell, J. P., McCloy, R. A., Oppler, S. H., ve Sager, C. A. (1993). A theory of performance. In N. Schmitt, ve W. C. Borman (Eds.), Personnel Selection in Organizations (pp. 35-70). New York: Wiley.

Campbell, J. P., Mchenry, J. J. ve Wise, L. L. (1990). Modeling job performance in a population of jobs. Personnel Psychology, 43(2), 313-333. doi: 10.1111/j.1744-6570.1990.tb01561.x

Carmeli, A. ve Josman, Z. E. (2006). The relationship among emotional intelligence, task performance, and organizational citizenship behaviors. Human Performance, 19(4), 403-419. doi:10.1207/s15327043hup1904_5

Castillo, M. Á. ve Valle, I. D. (2017). Is emotional intelligence the panacea for a better job performance? A study on low-skilled back office jobs. Employee Relations, 39(5), 683-698. doi:10.1108/ER-11-2016-0216

Cherniss, C. (2000). Social and emotional competence in the workplace. In R. Bar-On ve J. D. A. Parker (Eds.), The Handbook of Emotional Intelligence: The theory and practice of development, evaluation, education, and application-at home, school, and in the workplace (pp. 433-458). San Fransisco: Josey Bass.

Côté, S. ve Miners, C. T. (2006). Emotional intelligence, cognitive intelligence, and job performance. Administrative Science Quarterly, 51(1), 1-28. doi: 10.2189/asqu.51.1.1

Day, A. L. ve Carroll, S. A. (2004). Using an ability-based measure of emotional intelligence to predict individual performance, group performance, and group citizenship behaviors. Personality and Individual Differences, 36(6), 1443-1458. doi: 10.1016/S0191-8869(03)00240-X

Develi, A. (2020). Calısma yeterliliği, iș tatmini ve görev performansı ilişkisini belirlemeye yönelik bir arastırma (Doktora Tezi). Osmaniye Korkut Ata Üniversitesi Sosyal Bilimler Enstitüsü, Osmaniye. 
Dirican, A. H. (2013). Duygusal zekanın örgütsel vatandaşlık davranısı ve üretkenlik karşıtı davramıslar üzerine etkisi (Doktora Tezi). Gebze Yüksek Teknoloji Enstitüsü Sosyal Bilimler Enstitüsü, Kocaeli.

Feyerherm, A. E. ve Rice, C. L. (2002). Emotional intelligence and team performance: The good, the bad and the ugly. The International Journal of Organizational Analysis, 10(4), 343-362. doi: 10.1108/eb028957

Gardner, H. (1983). Frames of mind: The theory of multiple intelligences. New York: Basic Books.

Goleman, D. (1995). Emotional intelligence: Why it can matter more than IQ. London: Bloomsbury Publishing.

Goleman, D. (2001). Emotional intelligence: Issues in paradigm building. In C. Cherniss, ve D. Goleman(Eds.), The emotionally intelligent workplace: How to select for,measure, and improve emotional intelligence in individuals, groups, and organizations (pp. 13-26). New York: Jossey-Bass.

Gökçen Kapusuz, A. (2019). İş hayatında duygusal zekâ perspektifinden örgütsel sosyalleşme süreci, Manas Sosyal Arastirmalar Dergisi, 8(1), 231-245. doi: 10.33206/mjss.518971.

Guilford, J. P. (1956). The structure of intellect. Psychological Bulletin, 53(4), 267-293. doi:10.1037/h0040755

Gürbüz, S. ve Yüksel, M. (2008). Çalışma ortamında duygusal zeka: İş performansı, iş tatmini, örgütsel vatandaşlık davranışı ve bazı demografik özelliklerle ilişkisi. Doğuş Üniversitesi Dergisi, 9(2), 174-190. Erişim Adresi: http://journal.dogus.edu.tr/index.php/duj/article/view/68/83

Higgs, M. (2004). A study of the relationship between emotional intelligence and performance in UK call centres. Journal of Managerial Psychology, 19(4), 442-454. doi: 10.1108/02683940410537972

Jamshed, S. ve Majeed, N. (2019). Relationship between team culture and team performance through lens of knowledge sharing and team emotional intelligence. Journal of Knowledge Management, 23(1), 90-109. doi: 10.1108/JKM-04-2018-0265

Kamassi, A., Boulahlib, L., Manaf, N. A. ve Omar, A. (2021). Emotional labour strategies and employee performance: The role of emotional intelligence. Management Research Review, 43(2), 133-149. doi: 10.1108/MRR03-2019-0097

Keser, A. (2006). Çă̆rı merkezi çalışanlarında iş yükü düzeyi ile iş doyumu ilişkisinin araştırılması, Kocaeli Üniversitesi Sosyal Bilimler Enstitüsü Dergisi, 11(1), 100-119. Erişim Adresi: http://kosbed.kocaeli.edu.tr/sayi11/keser.pdf

Kim, H. T. (2020). Linking managers' emotional intelligence, cognitive ability and firm performance: Insights from Vietnamese firms. Cogent Business ve Management, 7(1), 1-22. doi: 10.1080/23311975.2020.1829272

Matthews, G., Zeidner, M. ve Roberts, R. D. (2002). Emotional intelligence science and myth. Massachusetts: The MIT Press.

Mayer, J. D. (2001). A field guide to emotional inlelligence. In J. V. Ciarrochi, J. P. Forgas, ve J. D. Mayer (Eds.), Emotional intelligence in everyday life: A scientific inquiry (pp. 3-24). New York: Psychology Press.

Mayer, J. D., DiPaolo, M. ve Salovey, P. (1990). Perceiving affective content in ambiguous visual stimuli: A component of emotional intelligence. Journal of Personality Assessment, 54(3-4), 772-781. doi: 10.1080/00223891.1990.9674037

Mayer, J. D., Salovey, P. ve Caruso, D. (2000a). Models of emotional intelligence. In R. J. Sternberg (Ed.), Handbook of emotional intelligence (pp. 396-422). Cambridge: Cambridge University Press.

Mayer, J. D., Salovey, P. ve Caruso, D. R. (2000b). Emotional intelligence as zeitgeist, as personality, and as a mental ability. In R. Bar-On, ve J. D. Parker (Eds.), The handbook of emotional intelligence: The theory and practice of development, evaluation, education, and application-at home, school, and in the workplace (pp. 92-117). San Fransisco: Josey Bass.

Menges, J. I. ve Bruch, H. (2009). Organizational emotional intelligence and performance: an empirical study. In C. E. Hartel, W. J. Zerbe, ve N. M. Ashkanasy (Eds.), Emotions in groups, organizations and cultures (Research on Emotion in Organizations, Vol. 5) (pp. 181-209). Bingley: Emerald Group Publishing Limited. doi: 10.1108/S17469791(2009)0000005010

Molina, D. C., Déniz-Déniz, M. C. ve García-Cabrera, A. M. (2019). The HR decision-maker's emotional intelligence and SME performance. Management Research Review, 43(1), 56-81. doi: 10.1108/MRR-10-2018-0373

Motowidlo, S. J., ve Kell, H. J. (2012). Job performance. In I. B. Weiner, N. W. Schmitt, ve S. Highhouse(Eds.), Handbook of psychology, Vol. 12 Industrial and organizational psychology (pp. 82-103). New Jersey: Wiley. 10.1002/9781118133880.hop212005

Motowidlo, S. J. ve Scotter, J. R. (1994). Evidence that task performance should be distinguished from contextual performance. Journal of Applied Psychology, 79(4), 475-480. doi: 10.1037/0021-9010.79.4.475

Nel, H. ve Villiers, W. S. (2004). The relationship between emotional intelligence and job performance in a call centre environment. SA Journal of Industrial Psychology, 30(3), 75-81. doi: 10.1016/j.sbspro.2014.03.650

O'Boyle, E. H., Humphrey, R. H., Pollack, J. M., Hawver, T. H. ve Story, P. A. (2011). The relation between emotional intelligence and job performance: A meta-analysis. Journal of Organizational Behavior, 32(5), 788-818. doi: 10.1002/job.714

O'Connor, P. J., Hill, A., Kaya, M. ve Martin, B. (2018). The measurement of emotional intelligence: A critical review of the literature and recommendations for researchers and practitioners. Frontiers in Psychology, 10, 1-19. doi: 10.3389/fpsyg.2019.01116

Özbezek, B. D. ve Paksoy, H. M. (2017). Liderlik etme motivasyonu ve duygusal zekâ arasındaki ilişkide öz yeterliliğ̈in rolü üzerine bir araştırma. International Journal of Disciplines Economics ve Administrative Sciences Studies, 3(4), 248-269. doi: 10.26728/ideas.42. 
Petrides, K. ve Furnham, A. (2000). On the dimensional structure of emotional intelligence. Personality and Individual Differences, 29(2), 313-320. doi: 10.1016/S0191-8869(99)00195-6

Rapisarda, B. A. (2002). The Impact of emotional intelligence on work team cohesiveness and performance. The International Journal of Organizational Analysis, 10(4), 363-379. doi: 10.1108/eb028958

Rezvani, A., Barrett, R. ve Khosravi, P. (2019). Investigating the relationships among team emotional intelligence, trust, conflict and team performance. Team Performance Management, 25(1/2), 120-137. doi: 10.1108/TPM-032018-0019

Salovey, P. ve Mayer, J. D. (1990). Emotional intelligence. Imagination, Cognition and Personality, 9(3), 185-211. doi: 10.2190/DUGG-P24E-52WK-6CDG

Shamsuddin, N. ve Rahman, R. A. (2014). The Relationship between emotional intelligence and job performance of call centre agents. International Conference on Innovation, Management and Technology Research (pp. 75-81). Malaysia: Procedia - Social and Behavioral Sciences.

Shih, H. A. ve Susanto, E. (2010). Conflict management styles, emotional intelligence, and job performance in public organizations. International Journal of Conflict Management, 21(2), 147-168. doi: 10.1108/10444061011037387

Singh, D. (2006). Emotional intelligence at work a professional guide (Third Edition). New Delhi: Response Books.

Taylor, G. J., Parker, J. D. ve Bagby, R. M. (1999). Emotional intelligence and the emotional brain: Points of convergence and implications for psychoanalysis. The Journal of the American Academy of Psychoanalysis, 27(3), 339354. doi: 10.1521/jaap.1.1999.27.3.339

Thorndike, E. L. (1920). Intelligence and its uses. Harper's Magazine, 140, 227-235. Erişim Adresi: https://psycnet.apa.org/record/1920-10067-001

Turhan, M. ve Çetinsöz, B. C. (2019). Duygusal zekâ ve motivasyon arasındaki ilişki: Turizm programı öğrencileri üzerine bir araştırma. Elektronik Sosyal Bilimler Dergisi 18(69), 268-287. doi:10.17755/esosder.438269

Viswesvaran, C. ve Ones, D. S. (2000). Perspectives on models of job performance. International Journal of Selection and Assessment, 8(4), 216-226. doi: 10.1111/1468-2389.00151

Waldman, D. A. ve Spangler, W. D. (1989). Putting together the pieces: A closer look at the determinants of job performance. Human Perfromance, 2(1), 29-59. doi: 10.1207/s15327043hup0201_2

Wong, C. S. ve Law, K. S. (2002). The effects of leader and follower emotional intelligence on performance and attitude: An exploratory study. The Leadership Quarterly, 13(3), 243-274. doi: 10.1016/S1048-9843(02)00099-1

Yazıcıŏ̆lu, Y. ve Erdoğan, S. (2004). SPSS Uygulamal Bilimsel Arastırma Yöntemleri. Ankara: Detay Yayıncilık.

Yoke, L. B. ve Panatik, S. A. (2015). Emotional Intelligence And Job Performance Among School Teachers. Asian Social Science, 11(13), 227-234. doi: 10.5539/ass.v11n13p227

Zeidner, M., Matthews, G. ve Roberts, R. D. (2004). Emotional intelligence in the workplace: A critical review. Applied Psychology: An International Review, 53(3), 371-399. doi: 10.1111/j.1464-0597.2004.00176.x

\section{EXTENDED ABSTRACT}

One of the most valuable resources of an organization is undoubtedly human resources. The job performance of human resources affects the performance of the organization and therefore plays a key role in the effectiveness and continuity of organizations. There are conflicting views that have been presented from the past to the present about the place of emotions in working life. While it was thought that the employee should not bring his / her emotions into the job in the past, later, the opinion has emerged that this is not possible due to human nature and even that emotions can allow employees to do their jobs better. Numerous studies show that around two-thirds of the competencies associated with superior performance are emotional or social qualities (Cherniss, 2000, pp. 433-434). Although emotional intelligence affects the job performance of employees in every industry, it has a greater impact, especially on jobs in the service sector where employees interact directly with customers (O'Boyle, Humphrey, Pollack, Hawver, \& Story, 2011, s. 793). Because in these jobs, emotional abilities such as understanding the wishes and needs of the customer, empathizing, or managing their own emotions are important parts of the employee's job performance. Employees of call centers, which are in the service sector and constitute the sample of the research, may have to use the activities of using, organizing, and evaluating emotions intensely, which are a reflection of their emotional intelligence. In this context, the purpose of the study is to determine whether this reflection affects the job performance of the employees. The Structural equation model has been used to test research hypotheses. Emotional intelligence in line with the determined research purpose will be discussed in four dimensions: self-emotional appraisal, others' emotional appraisal, use of emotion, and regulation of emotion. There are many empirical studies in the literature dealing with the variables between concepts. In these studies, it has been seen that the performance measurement of employees is carried out through Likert-type scales. In this study, unlike many other types of empirical research, an analysis has been made using the employee's performance scores determined by the organization and obtained based on multiple objective performance criteria. In this respect, the research differs from the research in which the employee evaluates his / her own 
performance and, provides the opportunity to test the research hypotheses on objective job performance results. The universe of the research consists of all employees of a call center operating in Ordu province. The firm determined as the research universe operates as a subsidiary of a telecommunications company operating at the national level. The firm continues its activities in many regions of Turkey. The call center, which constitutes the research universe, has 349 personnel. In the research aimed to access the whole universe, an online questionnaire form was sent to all employees, and feedback was obtained from 219 personnel. The Wong and Law Emotional Intelligence Scale (WLEIS) was adopted to measure the emotional intelligence of employees. To measure the individual job performance of the employees, monthly performance scores announced by their institutions have been used.

In the research, the performance scores of the employees have been categorized based on the score ranges determined by the company for the performance level, to test in the structural equation model. As a result of this classification, employees with unsuccessful performance levels have been coded as " 1 ", employees with medium performance levels as "2", and employees with successful performance levels as " 3 ". As a result of the multiple confirmatory factor analysis conducted to reveal the construct validity of the emotional intelligence scale, it has been found that the scale showed a distribution like the original four-factor structure ( $\mathrm{p}<0.01$ significance level x2 / df: 2.529, RMSEA: 0.078, NFI: 0.907, IFI; 0.935, GFI: 0.886). Cronbach Alpha internal consistency coefficients of scale dimensions, others' emotional appraisal: 0.863; self-emotional appraisal: 0.892; use of emotion: 0.792; regulation of emotion has been determined as 0.865 . In the study, firstly, the relationships between organizational variables in the research model have been tried to be determined. It has been found that there was a relationship between only one of the emotional intelligence sub-dimensions and job performance. It was determined that there is a positive significant relationship between the use of emotions and job performance (r:, 201). After this stage, the relationship between the level of use of emotions and job performance has been tested with the structural equation model. The model's goodness of fit index values have been found to have acceptable fit and good fit values at the significance level of $\mathrm{p}<0.001$ ( $\mathrm{x} 2$ / df: 3.563; RMSEA: 0.78; NFI: 0.960; CFI: 0.969; GFI: 0.975). The path of the structural equation model drawn to determine the effect of the use of emotion on job performance was found to have a standardized regression weight at $\mathrm{p}<0.005$ significance level (0.212). Employees who can positively direct (use) their emotions in terms of emotional intelligence motivate themselves to be talented people, set goals for the future, and try to do their best to achieve this specific goal. At this point, first, it will be more advantaged for the company to choose candidates who can set goals and direct their feelings to them positively. In addition, senior managers and team leaders should take initiatives to increase the self-competence and self-efficiency of employees and motivate employees to achieve weekly and monthly performance targets. This research has been conducted only on call center employees due to time and space constraints. In addition, the research sample consists of only one call center of a corporate firm operating at the national level. 